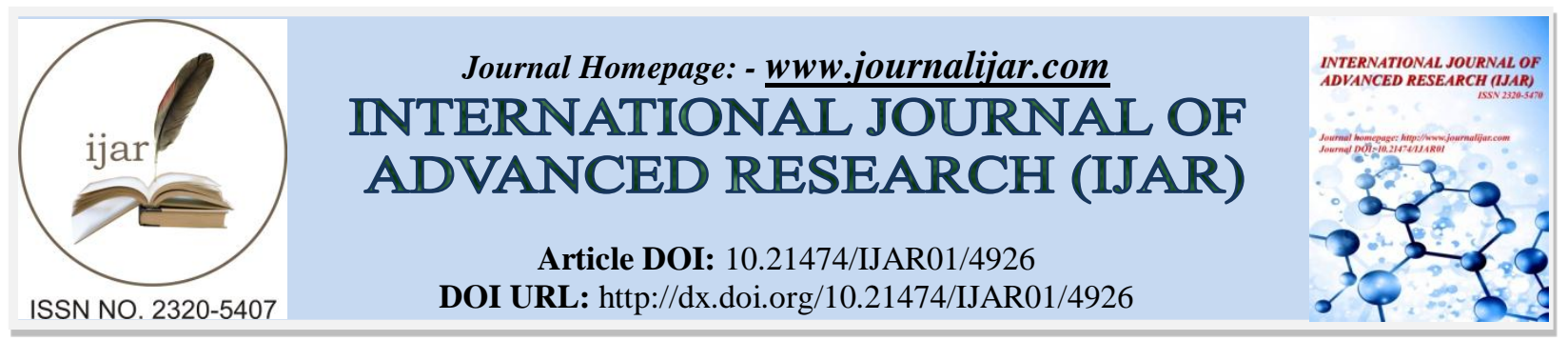

RESEARCH ARTICLE

\title{
DEBIT MODELING USING ARIMA METHOD TO DETERMINE OPERATIONAL PATTERN OF SELOREJO DAM.
}

\author{
Pitojo Tri Juwono ${ }^{1}$, Widandi Soetopo ${ }^{1}$ and Bambang Pramujo ${ }^{2}$. \\ 1. Lecturer of Water Engineering Department, Malang Brawijaya University. \\ 2. Student of Water Engineering Magister, Faculty of Engineering, Malang Brawijaya University.
}

\section{Manuscript Info}

(1........................

Manuscript History

Received: 23 May 2017

Final Accepted: 25 June 2017

Published: July 2017

Key words:-

ARIMA, debit inflow, reservoir operational pattern, Selorejo Dam.

\section{Abstract}

Selorejo Dam is located in Pandansari Village, Ngantang District, Malang Regency. The exact spot is at Konto River, a tributary of Brantas River. This dam has very important functions such as for electric generation and irrigation. It is very old dam with construction completed in 1970 but now subjected to shallowing due to a high sedimentation rate. The decreasing reservoir volume of the dam has impacted dam function, and therefore, it is necessary to formulate a better plan for reservoir operational pattern to manage properly the existing water volume. Recently, in planning the operational pattern of the reservoir, Perum Jasa Tirta I (PJT-I) as the manager of Selorejo Dam uses feasible debit to predict debit inflow. In this study, debit inflow is predicted using ARIMA method from also which new operational pattern of the reservoir can be established. This study uses 10-years data of 10-days debit inflow. Of these data, 9-years data are used to generate ARIMA model while 1-year data are used for calibration. The best ARIMA model in predicting debit inflow is ARIMA $(1,1,1)(2,1,1)^{36}$. Compared to other methods recently used, ARIMA has been proved as able to predict debit inflow in better way with smaller Relative Error (KR) than realized debit (Model's KR is 5.5 and Operator's (PJT-I) KR is 17.5)

Copy Right, IJAR, 2017,. All rights reserved.

\section{Introduction:-}

Selorejo Dam remains as part of Brantas River Region and it retains Konto and Kwayangan Rivers. The spread of dam's water stream extends to $236 \mathrm{~km}^{2}$. Some important functions of Selorejo Dam include electric generation and irrigation. It was completed in 1970, and therefore, it is very old dam with many problems, among other is high sedimentation rate.

The declining reservoir volume in Selorejo Dam is resolved by planning better operational pattern to optimize water production. In making this plan, the most influential factor is debit inflow, debit outflow, and physical condition of the dam. Feasible debit inflow is recently used by Perum Jasa Tirta I to plan the operational pattern of the reservoir. The prediction of debit inflow is derived from ARIMA model, and it is expected that this model will help giving better debit prediction that approaches the reality. 
This study uses ARIMA model because this model can give good prediction for seasonal time-series data, including debit inflow data.

Nigam et.al. (2009) said that ARIMA model is the proper approach to hydrology data because this model can resolve data that involve auto-correlation with timing and also that need exact explanation about base dynamic of items. This capacity is hardly found in the simple statistic tool such as regression analysis. Valipour et.al. (2012) admitted that ARIMA model has better performance than ARMA model because the former can produce stationary time-series at calibration and prediction phases. ARIMA is then used to predict monthly debit inflow for the next 12 months.

Main objective of this review is to make ARIMA model that is proper for predicting Selorejo Dam debit inflow and to use it in the planning of reservoir operational pattern.

The benefit of this study is to obtain the most proper ARIMA model for predicting reservoir debit inflow of Selorejo Dam as the consideration material for Perum Jasa Tirta I in planning reservoir operational pattern.

\section{Method Of Research:-}

Selorejo Dam is located in Pandansari Village, Ngantang District, Malang Regency. It stands at Konto River, a tributary of Brantas River, and just below its confuence with Kwayangan River. The site is $\pm 50 \mathrm{~km}$ at west of Malang City wih altitude over $650 \mathrm{~m}$ above sea level.

\section{Data Collection:-}

The used data in this study are described as following:

a. Reservoir debit inflow of Selorejo Dam in 10 years, at period 2003/2004 to 2012/2013.

b. Technical aspect of Selorejo Dam.

c. Reservoir operational pattern of Selorejo Dam.

\section{Methodology:-}

\section{Dam and Reservoir:-}

Retaining water excess during rain season to be used for meeting water demand and water production at time as necessary, and also controlling against water destructive capacity, then requires reservoir. Dam is a construction with piles of soil, rock, concrete and/or brick to retain and contain water, mining waste (tailing) or also mud. Reservoir is the artificial batch as the consequence of dam construction. Both dam and reservoir, and also their management, are aimed to increase the utilities of water resource and water purification, to improve the control over water destructive capacity and to secure the storage of tailing and mud (Republik Indonesia, 2010).

\section{Quantitative prediction:-}

River debit entering reservoir is greatly affected by season. Indonesia is a tropical country with two seasons in a year, respectively rain season and dry season. River debit is drawn in time-series with different pattern for each season. With adequate historical data, river debit rate can be predicted with quantitative method. Makridakis et.al (1988) asserted that quantitative prediction is applicable when three conditions are shown:

1. There is information of the past.

2. Information can be quantified into numerical data.

3. It is assumed that few pattern in the past may proceed to the future.

\section{Prediction Method:-}

Prediction is an act to count possible occurences in the future. Time-series data are used to predict the future based on the past value of certain variable (Makridakis et.al, 1988).

Autocorrelation Function (ACF):-

Autocorrelation coefficient explains the relationship between values in similar variable. Autocorrelation is a determinant tool to identify base pattern that describes data. It is used to recognize whether data are random, stationary, or seasonal (Arsyad, 1994). 


\section{Partial Autocorrelation Function (PACF):-}

Partial autocorrelation is used to measure the closeness rate of linear relationship between $\mathrm{Z}_{\mathrm{t}}$ and $\mathrm{Z}_{\mathrm{t}+\mathrm{k}}$ if the effect of time lag 1, 2, .... k-1 is considered as separated (Makridakis et.al., 1988).

\section{Time-Series Stationarity:-}

As noted by Makridakis et.al. (1988), stationarity signifies a condition that there is no addition or reduction in the data. Data must be horizontal along with time axis. In other words, data fluctuation remains around constant mean, not depending on time and variance of fluctuation. Basically, it remains constant over times. Stationary time-series are those whose basic statistic is characterized by the constant mean and variant over times (Hanke et.al., 2003).

\section{Seasonal ARIMA:-}

Hanke et.al. (2003) defined seasonal time-series as those with repeated change pattern. It changes every year. Seasonal prediction is then developed, usually involving selection between decomposition, multiplication, and addition, and then followed by estimating seasonal index from historical time-series. These indexes are used to put seasonal substance into the prediction or to separate certain effects of observation.

Seasonal ARIMA model is a part of flexible time-series model that is used to model seasonal data, including nonseasonal time-series. Seasonal ARIMA model is explained as following (Cryer, 1986; Box et.al., 1994):

$$
\phi_{p}(B) \Phi_{P}\left(B^{S}\right)(1-B)^{d}\left(1-B^{S}\right)^{D} Y_{t}=\theta_{q}(B) \Theta_{Q}\left(B^{S}\right) a_{t}
$$

with

$$
\begin{aligned}
& \phi_{p}(B)=1-\phi_{1} B-\phi_{2} B^{2}-\ldots-\phi_{p} B^{p} \\
& \Phi_{P}\left(B^{S}\right)=1-\Phi_{1} B^{S}-\Phi_{2} B^{2 S}-\ldots-\Phi_{P} B^{P S} \\
& \theta_{q}(B)=1-\theta_{1} B-\theta_{2} B^{2}-\ldots-\theta_{q} B^{q} \\
& \Theta_{Q}\left(B^{S}\right)=1-\Theta_{1} B^{S}-\Theta_{2} B^{2 S}-\ldots-\Theta_{Q} B^{Q S},
\end{aligned}
$$

$S$ is seasonal period length; $B$ is back shift operator; and $a_{t}$ is white noise series with zero mean and constant variance.

\section{Reservoir Operational Pattern:-}

Pursuant to the Government Regulation No.37/2010 about Dam, it is said that dam management plan is aimed for managing water resource in the dam. This plan accomodates reservoir operational pattern. This reservoir operational pattern comprises of several items:

1. Dry-year operational pattern.

2. Normal-year operational pattern; and

3. Rain-year operational pattern.

Reservoir operational pattern explains about the method of releasing water from reservoir based on current volume, water elevation at reservoir, water demand, and river capacity at downstream part of the dam.

\section{Operational Pattern of Selorejo Dam:-}

Selorejo Dam is annual reservoir functioned as the controller of flood during rain season. The presence of reservoir is quite useful to provide irrigation water debit needed by Pare and Jombang Regions in dry season in $4 \mathrm{~m}^{3} / \mathrm{second}$. It covers irrigation width of 5,700 ha in all irrigation systems of 22,000 ha, and it helps improving rice production of 7,500 tons/year. It is also useful to meet the demand of standard water for the industry. Water output from the dam is also useful for electric generation with power capacity of $1 \times 4.500 \mathrm{~kW}$, which then produces electrical power for \pm 49 millions $\mathrm{kWh}$ per year.

\section{Result And Discussion:-}

\section{Data of Selorejo Dam Debit inflow:-}

Data of debit inflow in Selorejo Dam are collected from Perum Jasa Tirta I. It is data of daily mean of debit inflow. Aligning with Selorejo Dam operational pattern in 10-days period, then data of daily mean of debit inflow are 
converted into data of 10-days mean debit inflow. Selorejo Dam operational pattern starts from December to November. In this study, debit inflow data are arranged for 10 periods from 2003/2004 to 2012/2013. Data of first 10-periods debit are used for modeling electric generation in ARIM, and data of 1-period are used for model calibration.

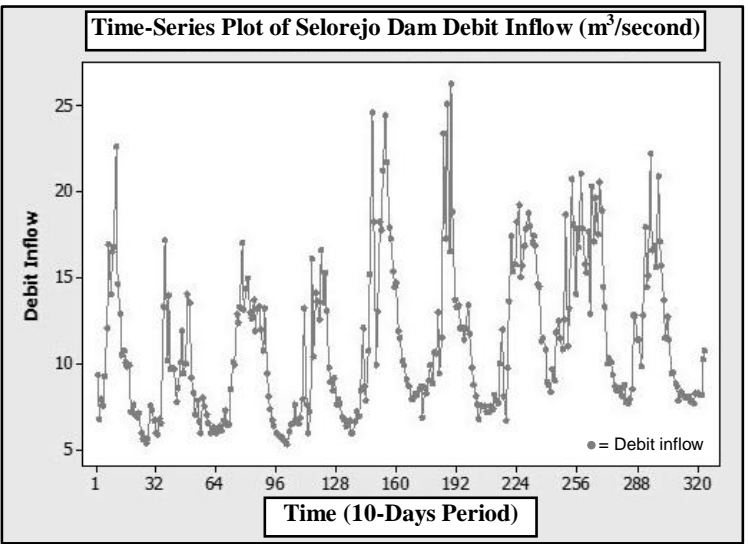

Figure 1:- Debit Inflow Data Plot of Selorejo Dam

The graphic above showes time-series plot data of 10-days mean debit inflow in Selorejo Dam. It indicates seasonal pattern. Data are not yet stationary, and data variance is too big. Data are also not yet stationary against variance. Proving the stationarity against variance, and also the median, Box-Cox Plot is then made to identify data stationarity against variance adn ACF Plot to see data stationarity against median.

\section{Stationarity Test Against Variance:-}

Figure 2 shows that data of 10-days mean debit inflow of Selorejo Dam are tested with Box-Cox Test, and it obtains $\lambda \neq 1$, meaning that data are not stationary against variance. Transformation of Box-Cox is then conducted resulting in $\lambda=1$. In first transformation, it is obtained that 10-days mean debit inflow of Selorejo Dam has been stationary against variance by $\lambda=1$ in Figure 3 .

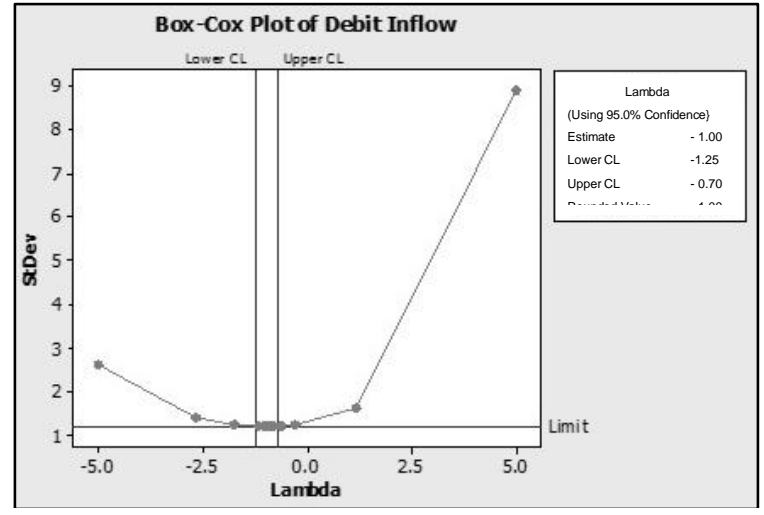

Figure 2:- Box-Cox Plot 


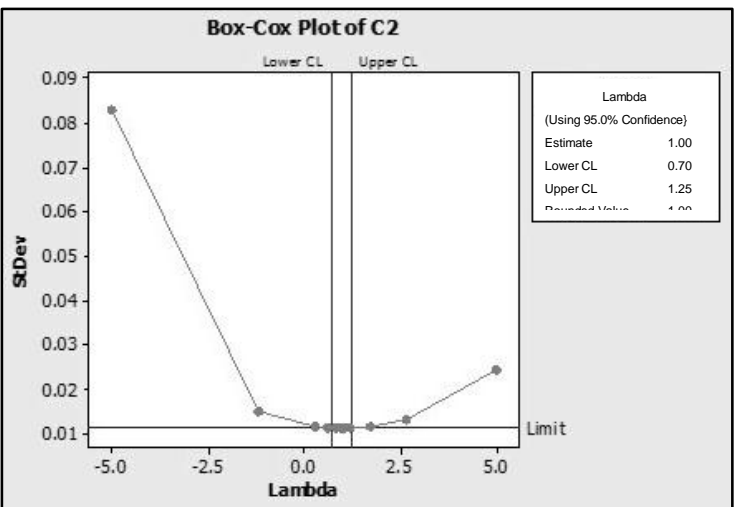

Figure 3:- First Transformation of Box-Cox Plot

\section{Stationarity against Median:-}

When stationarity against variance has been proved, then stationarity test is performed against mean, and it is detected using ACF Plot.

ACF Plot in Figure 4 indicates that data are not yet stationary, and therefore, it is made into stationarity with differencing at once (one-time). Stationary data are marked with unpatterned (random) lag which does not contain season.

ACF Plot is then made after one-time differencing. It is displayed in Figure 5 showing that data are stationary already. There is no seasonal substance and there is irregular pattern or also said as unpatterned.

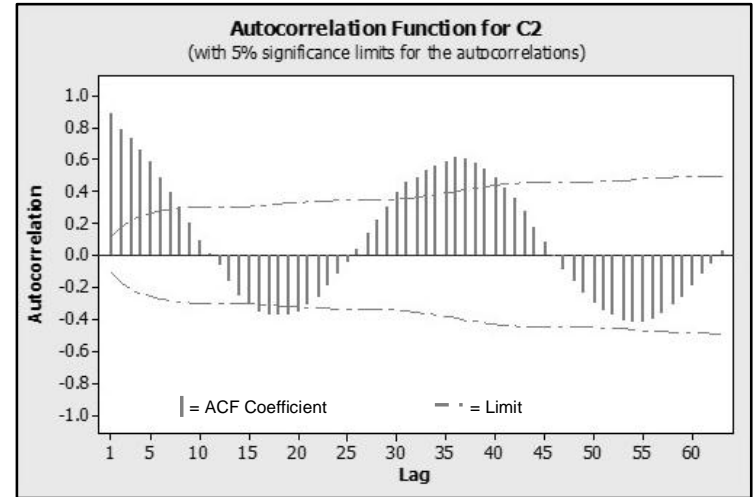

Figure 4:- ACF Plot

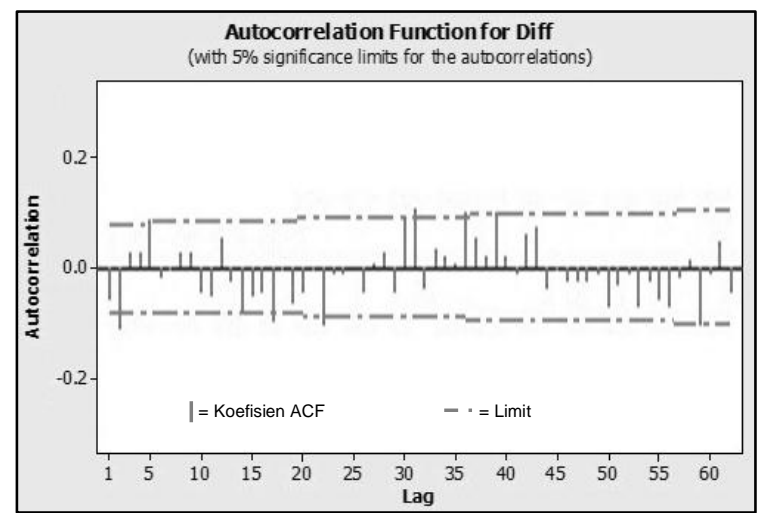

Figure 5:- ACF Plot with One-Time Differencing 


\section{ARIMA Model $(\mathbf{P}, \mathbf{D}, \mathbf{Q})(\mathbf{P}, \mathbf{D}, \mathbf{Q})^{\mathrm{S}}$ For Water Debit Data:-}

Based on ACF Plot after one-time differencing, there is cutoff after lag 2 and also seasonal cutoff at lag 36. Tentative model for non-seasonal AR is 1.2. Tentative model for seasonal AR is $\mathrm{P}=1.2$. One-time differencing process has produced orde $\mathrm{d}=1$ and reasonal order $\mathrm{D}=1$. Order $\mathrm{q}$ of MA Model can be determined from PACF Plot in Figure 6.

From PACF Plot, observation points of 10-days mean debit inflow are obtained and the characteristic of these points is dies-down. There are alternative models for MA Model at order $\mathrm{q}=1.2$ and also at seasonal MA order $\mathrm{Q}=1.2$ (assumed that it follows non-seasonal order). Based on ACF and PACF Plots, seasonal ARIMA tentative model is then prepared with seasonal order $\mathrm{S}=36$.

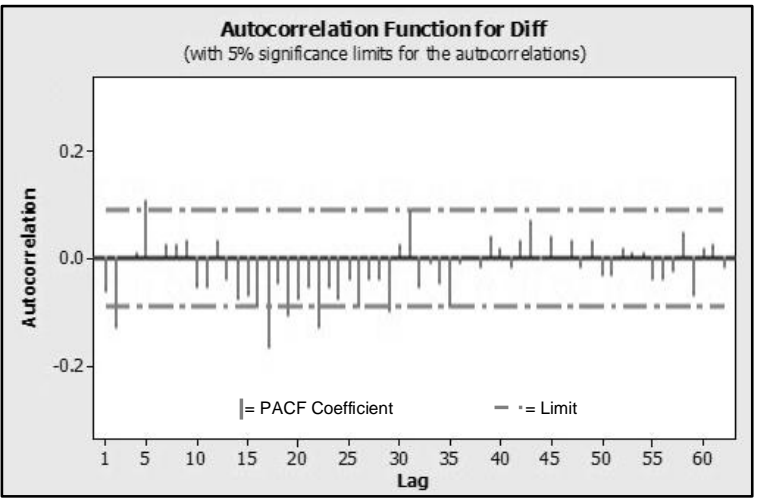

Figure 6:- PACF Plot

Table 1:- ARIMA Tentative Model and Model Compatibility Test.

\begin{tabular}{|r|l|l|r|r|r|r|l|}
\hline \multirow{2}{*}{ No. } & \multirow{2}{*}{ ARIMA } & & \multicolumn{4}{|c|}{ lag } & \multirow{2}{*}{ CONCLUSION } \\
\cline { 3 - 6 } & & & 12 & 24 & 36 & 48 & \\
\hline 1 & $(1,1,1)(1,1,1)$ & $p$-value & 0.220 & 0.912 & 0.965 & 0.947 & Model is feasible. \\
\hline 2 & $(1,1,2)(1,1,1)$ & $p$-value & 0.116 & 0.853 & 0.944 & 0.948 & Model is feasible. \\
\hline 3 & $(2,1,1)(1,1,1)$ & $p$-value & 0.112 & 0.839 & 0.928 & 0.928 & Model is feasible. \\
\hline 4 & $(1,1,1)(2,1,1)$ & $p$-value & 0.083 & 0.654 & 0.666 & 0.461 & Model is feasible. \\
\hline 5 & $(1,1,2)(2,1,1)$ & $p$-value & 0.040 & 0.526 & 0.509 & 0.369 & Model is not feasible. \\
\hline 6 & $(2,1,1)(2,1,1)$ & $p$-value & 0.007 & 0.424 & 0.690 & 0.629 & Model is not feasible. \\
\hline 7 & $(2,1,2)(1,1,1)$ & $p$-value & 0.061 & 0.771 & 0.899 & 0.899 & Model is feasible. \\
\hline 8 & $(2,1,2)(2,1,1)$ & $p$-value & 0.036 & 0.644 & 0.745 & 0.577 & Model is not feasible. \\
\hline 9 & $(1,1,1)(2,1,2)$ & $p$-value & 0.047 & 0.602 & 0.690 & 0.460 & Model is not feasible. \\
\hline 10 & $(1,1,2)(2,1,2)$ & $p$-value & 0.003 & 0.269 & 0.282 & 0.173 & Model is not feasible. \\
\hline 11 & $(2,1,1)(2,1,2)$ & $p$-value & 0.001 & 0.190 & 0.269 & 0.233 & Model is not feasible. \\
\hline 12 & $(2,1,2)(2,1,2)$ & $p$-value & 0.006 & 0.310 & 0.168 & 0.147 & Model is not feasible. \\
\hline 13 & $(1,1,1)(1,1,2)$ & $p$-value & 0.159 & 0.896 & 0.958 & 0.955 & Model is feasible. \\
\hline 14 & $(1,1,2)(1,1,2)$ & $p$-value & 0.002 & 0.214 & 0.431 & 0.501 & Model is not feasible. \\
\hline 15 & $(2,1,1)(1,1,2)$ & $p$-value & 0.083 & 0.824 & 0.941 & 0.947 & Model is feasible. \\
\hline 16 & $(2,1,2)(1,1,2)$ & $p$-value & 0.020 & 0.637 & 0.864 & 0.883 & Model is not feasible. \\
\hline
\end{tabular}

Seasonal ARIMA Model is $(\mathrm{p}, \mathrm{d}, \mathrm{q})(\mathrm{P}, \mathrm{D}, \mathrm{Q})^{\mathrm{S}}$. From previous stages, the rate of each ARIMA model parameter is obatined, and 16 ARIMA tentative models are shown in Table 1. Model feasibility test is done using Ljung-Box test statistic, and it shows that model is not feasible if p-value is less than 0.05

\section{Debit Prediction Using ARIMA Model:-}

Next stage is predicting debit inflow with the existing model. Debit prediction is done for period 2012/2013. The following is the prediction of 10-days mean debit inflow in Selorejo Dam for period 2012/2013 based on estimation of ARIMA Model $(1,1,1)(2,1,1)^{36}$. 


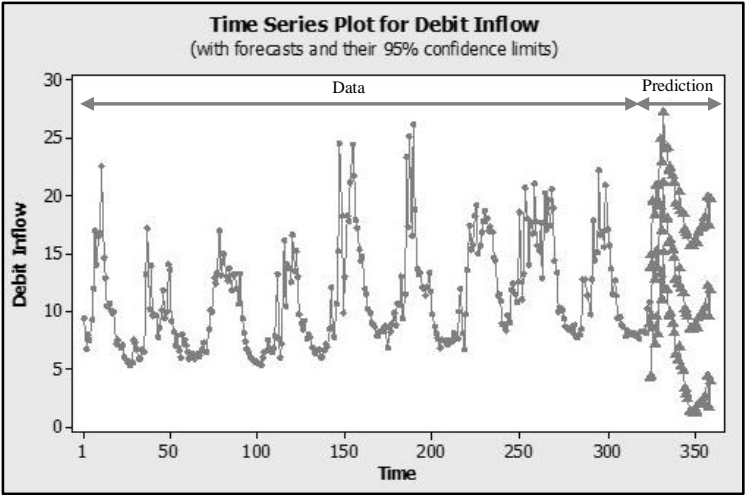

Figure 7:- Prediction of Debit Inflow With ARIMA Model $(1,1,1)(2,1,1)^{36}$

Table 2:- Recapitalization of Results from ARIMA Model Testing

\begin{tabular}{|l|r|r|r|r|}
\hline & \multicolumn{5}{|c|}{ ARIMA Model } \\
\cline { 2 - 6 } & $(1,1,1)(1,1,1)$ & $(1,1,2)(1,1,1)$ & $(2,1,1)(1,1,1)$ & $(1,1,1)(2,1,1)$ \\
\hline MSE (Debit) & 5.64 & 5.72 & 5.70 & 5.77 \\
\hline KAR (Debit) & 0.15 & 0.20 & 0.21 & 0.15 \\
\hline MAPE (Debit) & 7.09 & 7.84 & 8.00 & 9.67 \\
\hline MAD (Debit) & 2.20 & 2.84 & 2.93 & 2.02 \\
\hline MSD (Debit) & 9.55 & 13.97 & 14.48 & 8.08 \\
\hline T-test(Debit) & Meet Condition & Not Meet Condition & Not Meet Condition & Meet Condition \\
\hline T-test (Volume) & Meet Condition & Not Meet Condition & Not Meet Condition & Meet Condition \\
\hline KR (Volume) & 10.84 & 19.27 & 19.99 & 5.50 \\
\hline & \multicolumn{5}{|c|}{ ARIMA Model } \\
\cline { 2 - 6 } & $(2,1,2)(1,1,1)$ & $(1,1,1)(1,1,2)$ & $(2,1,1)(1,1,2)$ & \multicolumn{1}{c|}{ POWAA } \\
\hline MSE (Debit) & 5.64 & 5.81 & 5.84 & \\
\hline KAR (Debit) & 0.18 & 0.15 & 0.19 & 0.15 \\
\hline MAPE (Debit) & 7.57 & 7.18 & 7.76 & 6.53 \\
\hline MAD (Debit) & 2.61 & 2.24 & 2.67 & 2.46 \\
\hline MSD (Debit) & 12.24 & 10.41 & 12.71 & 13.49 \\
\hline T-test (Debit) & Not Meet Condition & Meet Condition & Not Meet Condition & Not Meet Condition \\
\hline T-test (Volume) & Not Meet Condition & Meet Condition & Not Meet Condition & Not Meet Condition \\
\hline KR (Volume) & 16.34 & 12.50 & 16.86 & 17.80 \\
\hline
\end{tabular}

\section{The Selection of Best Model:-}

Result of prediction of 10-days mean debit inflow in Figure 7 ascertains that model is meeting the condition of Ljung-Box Test. It is then calibrated against 10-days mean debit inflow as masured in period 2012/2013. The calibration is done by searching the rates of MSE (Mean Square Error), KAR (mean absolute error), MAPE (Mean Absolute Percentage Error), MAD (Mean Absolute Deviation), MSD (Mean Squared Deviation), t-test, dan KR (relative error). Both t-test and KR are calibrated not only from debit but also volume of the reservoir. Result of each calibration is shown in Table 2.

Related with reservoir management, the base water is that in the retention. Therefore, the selected model is that with the smallest relative error (KR), respectively ARIMA Model $(1,1,1)(2,1,1)^{36}$ with KR 5.50. This model involves equation:

$\mathrm{Z}_{\mathrm{t}}=\quad 2.36 \mathrm{Z}_{\mathrm{t}-1}-1.72 \mathrm{Z}_{\mathrm{t}-2}+0.36 \mathrm{Z}_{\mathrm{t}-3}-0.18 \mathrm{Z}_{\mathrm{t}-36}+0.42 \mathrm{Z}_{\mathrm{t}-37}-0.31 \mathrm{Z}_{\mathrm{t}-38}+0.06 \mathrm{Z}_{\mathrm{t}-39}-0.47 \mathrm{Z}_{\mathrm{t}-72}+1.11 \mathrm{Z}_{\mathrm{t}-73}-0.81 \mathrm{Z}_{\mathrm{t}-74}+$ $0.17 \mathrm{Z}_{\mathrm{t}-75}+0.66 \mathrm{a}_{\mathrm{t}-37}$

\section{The Comparison Between Data of Debit and Volume in Selorejo Dam:-}

The following is a graphic that compares debit inflow across measurement results, precisely between those from ARIMA prediction and those from the planning of Perum Jasa Tirta I. The comparison is displayed in Figure 8. 


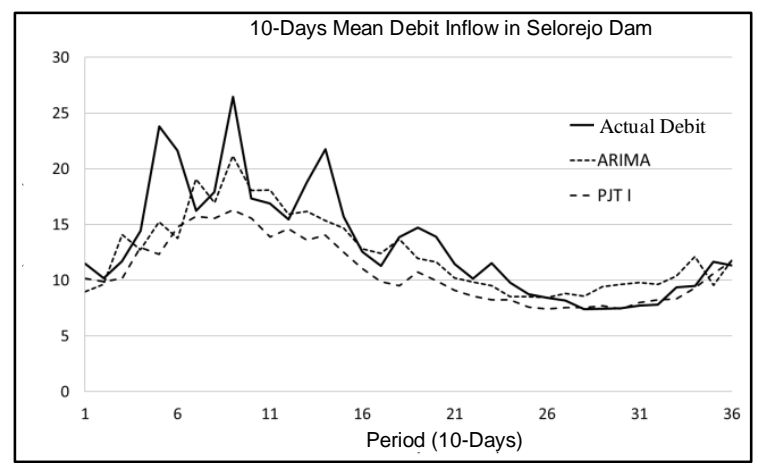

Figure 8:- The Comparison of 10-Days Mean Debit Inflow in Selorejo Dam.

\section{Operational Pattern of Selorejo Dam:-}

After 10-days mean debit inflow in Selorejo Dam, then operational pattern of reservoir is planned for period 2012/2013. The following is the result of operational pattern plan for the reservoir of Selorejo Dam. The following is the result of the planning of Selorejo Dam operational pattern based on the result of debit inflow prediction using ARIMA method, its comparison with operational pattern plan based on PJT-I, and its realization.

Operational pattern with debit inflow as predicted from ARIMA $(1,1,1)(2,1,1)^{36}$.

Table 3:-. Operational Pattern Plan with ARIMA Model Result

\begin{tabular}{|c|c|c|c|c|c|c|c|}
\hline & \multirow{2}{*}{\multicolumn{2}{|c|}{$\begin{array}{l}\text { INFI TURB'INE } \\
\text { / sec } \mathrm{m}^{3} / \mathrm{sec} \mathrm{T}^{3} / \mathrm{sec}\end{array}$}} & & & & \multirow{3}{*}{$\begin{array}{c}\text { ELEVASI } \\
\text { AKHIR } \\
\mathbf{m}\end{array}$} \\
\hline & & & & \multicolumn{2}{|c|}{ 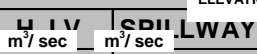 } & \multirow{2}{*}{$\begin{array}{l}\text { TOTAL } \\
\mathrm{m}^{3} / \mathrm{dtk}\end{array}$} & \\
\hline & & $\mathrm{m}^{\overline{3}} / \mathrm{dtk}$ & $\mathrm{m}^{3} / \mathrm{dtk}$ & $\mathrm{m}^{3} / \mathrm{dtk}$ & $\mathrm{m}^{3 / \mathrm{dtk}}$ & & \\
\hline \multicolumn{2}{|l|}{ DEC } & & & & & & 612.00 \\
\hline \multirow{3}{*}{ DES } & 1 & 8.98 & 12.50 & - & - & 12.50 & 609.79 \\
\hline & 2 & 9.63 & 13.00 & - & - & 13.00 & 607.20 \\
\hline & 3 & 14.09 & 14.00 & - & - & 14.00 & 607.29 \\
\hline \multirow{3}{*}{ JAN } & 1 & 12.75 & 14.00 & - & - & 14.00 & 606.17 \\
\hline & 2 & 15.22 & 14.00 & - & - & 14.00 & 607.26 \\
\hline & 3 & 13.76 & 14.00 & - & - & 14.00 & 607.03 \\
\hline \multirow{3}{*}{ FEB } & 1 & 19.08 & 14.00 & - & - & 14.00 & 610.80 \\
\hline & 2 & 16.95 & 14.00 & - & - & 14.00 & 612.54 \\
\hline & 3 & 21.18 & 14.00 & - & - & 14.00 & 615.30 \\
\hline \multirow{3}{*}{$\begin{array}{l}\text { MAR } \\
\text { MAY }\end{array}$} & 1 & 18.04 & 13.00 & - & - & 13.00 & 617.28 \\
\hline & 2 & 18.08 & 13.00 & - & - & 13.00 & 618.98 \\
\hline & 3 & 15.93 & 13.00 & - & - & 13.00 & 619.94 \\
\hline \multirow{3}{*}{ APR } & 1 & 16.19 & 13.00 & - & - & 13.00 & 620.82 \\
\hline & 2 & 15.35 & 13.00 & - & - & 13.00 & 621.44 \\
\hline & 3 & 14.65 & 13.00 & - & - & 13.00 & 621.85 \\
\hline \multirow{3}{*}{ MEI } & 1 & 12.80 & 13.00 & - & - & 13.00 & 621.80 \\
\hline & 2 & 12.42 & 12.80 & - & - & 12.80 & 621.70 \\
\hline & 3 & 13.70 & 12.60 & - & - & 12.60 & 622.00 \\
\hline \multirow{3}{*}{ JUN } & 1 & 11.95 & 12.50 & - & - & 12.50 & 621.86 \\
\hline & 2 & 11.65 & 12.50 & - & - & 12.50 & 621.66 \\
\hline & 3 & 10.20 & 12.40 & - & - & 12.40 & 621.10 \\
\hline \multirow{3}{*}{ OCT . } & 1 & 9.85 & 12.30 & - & - & 12.30 & 620.44 \\
\hline & 2 & 9.50 & 12.10 & - & - & 12.10 & 619.70 \\
\hline & 3 & 8.51 & 12.10 & - & - & 12.10 & 618.48 \\
\hline \multirow{3}{*}{$\begin{array}{l}\text { NOV } \\
\text { HUT }\end{array}$} & 1 & 8.54 & 12.00 & - & - & 12.00 & 617.30 \\
\hline & 2 & 8.44 & 12.00 & - & - & 12.00 & 615.94 \\
\hline & 3 & 8.82 & 11.00 & - & - & 11.00 & 614.93 \\
\hline \multirow{3}{*}{ SEP } & 1 & 8.55 & 11.00 & - & - & 11.00 & 613.79 \\
\hline & 2 & 9.42 & 10.50 & - & - & 10.50 & 613.25 \\
\hline & 3 & 9.63 & 10.00 & - & - & 10.00 & 613.06 \\
\hline \multirow{3}{*}{ OKT } & 1 & 9.81 & 9.31 & - & - & 9.31 & 613.32 \\
\hline & 2 & 9.64 & 9.50 & - & - & 9.50 & 613.39 \\
\hline & 3 & 10.37 & 10.00 & - & - & 10.00 & 613.59 \\
\hline \multirow{3}{*}{ NOP } & 1 & 12.14 & 11.50 & - & - & 11.50 & 613.91 \\
\hline & 2 & 9.55 & 12.50 & - & - & 12.50 & 612.39 \\
\hline & 3 & 11.81 & 12.50 & - & - & 12.50 & 612.00 \\
\hline
\end{tabular}


a. Operational pattern plan for Selorejo Dam based on PJT-I

Table 4:- Rencana Pola Operasi Oleh PJT-I

\begin{tabular}{|c|c|c|c|c|c|c|c|}
\hline \multirow{2}{*}{\multicolumn{2}{|c|}{ 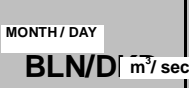 }} & \multirow{2}{*}{ II $_{\mathrm{m}^{3} / \mathrm{sec}}^{\text {TURBINE }} \mathbf{W}$} & \multicolumn{4}{|c|}{ OL $\underset{\substack{\text { FLNAL } \\
\text { ELEATION }}}{V}$} & \multirow{3}{*}{$\begin{array}{c}\text { ELEVASI } \\
\text { AKHIR } \\
\mathbf{m}\end{array}$} \\
\hline & & & $\overline{\sec } \mathrm{lR}\left\lceil\overline{\mathrm{m}}^{-\mathrm{s}} / \mathrm{sec}\right.$ & $\dot{\mathrm{m}}^{3} / \ddot{\mathrm{sec}}$ & \multirow{2}{*}{\begin{tabular}{|c|} 
SPILLWAY \\
$\mathrm{m}^{3} / \mathrm{dtk}$ \\
\end{tabular}} & \multirow{2}{*}{$\begin{array}{l}\text { TOTAL } \\
\mathrm{m}^{3} / \mathrm{dtk}\end{array}$} & \\
\hline & & $\mathrm{m}^{3} /$ dtk & $\mathrm{m}^{3} /$ dtk & $\mathrm{m}^{3} / \mathrm{dtk}$ & & & \\
\hline \multicolumn{2}{|l|}{ DEC } & & & & & & 612.00 \\
\hline \multirow{3}{*}{ DES } & 1 & 10.17 & 9.25 & - & - & 9.25 & 612.40 \\
\hline & 2 & 9.87 & 9.25 & - & - & 9.25 & 612.67 \\
\hline & 3 & 10.16 & 10.00 & - & - & 10.00 & 612.74 \\
\hline \multirow{3}{*}{ JAN } & 1 & 12.95 & 12.50 & - & - & 12.50 & 612.94 \\
\hline & 2 & 12.32 & 12.50 & - & - & 12.50 & 612.86 \\
\hline & 3 & 14.77 & 12.50 & - & - & 12.50 & 613.94 \\
\hline \multirow{3}{*}{$\begin{array}{l}\text { FEB } \\
\text { MAY }\end{array}$} & 1 & 15.72 & 13.00 & - & - & 13.00 & 615.11 \\
\hline & 2 & 15.56 & 14.00 & - & - & 14.00 & 615.79 \\
\hline & 3 & 16.29 & 14.00 & - & - & 14.00 & 616.38 \\
\hline \multirow{3}{*}{ MAR } & 1 & 15.56 & 13.00 & - & - & 13.00 & 617.12 \\
\hline & 2 & 13.87 & 12.70 & - & - & 12.70 & 617.46 \\
\hline & 3 & 14.61 & 12.00 & - & - & 12.00 & 618.29 \\
\hline \multirow{3}{*}{ APR } & 1 & 13.58 & 11.50 & - & - & 11.50 & 618.88 \\
\hline & 2 & 14.03 & 9.25 & - & - & 9.25 & 620.26 \\
\hline & 3 & 12.50 & 9.25 & - & - & 9.25 & 621.20 \\
\hline \multirow{3}{*}{ MEI } & 1 & 11.05 & 9.25 & - & - & 9.25 & 621.72 \\
\hline & 2 & 9.88 & 9.25 & - & - & 9.25 & 621.90 \\
\hline & 3 & 9.51 & 9.25 & - & - & 9.25 & 622.00 \\
\hline \multirow{3}{*}{ JOV } & 1 & 10.73 & 12.05 & - & - & 12.05 & 621.62 \\
\hline & 2 & 9.94 & 12.50 & - & - & 12.50 & 620.88 \\
\hline & 3 & 9.11 & 12.25 & - & - & 12.25 & 619.98 \\
\hline \multirow{3}{*}{ JUL } & 1 & 8.57 & 12.25 & - & - & 12.25 & 618.92 \\
\hline & 2 & 8.25 & 11.48 & - & - & 11.48 & 617.99 \\
\hline & 3 & 8.26 & 11.18 & - & - & 11.18 & 617.06 \\
\hline \multirow{3}{*}{ AGT } & 1 & 7.58 & 10.70 & - & - & 10.70 & 616.16 \\
\hline & 2 & 7.42 & 9.28 & - & - & 9.28 & 615.44 \\
\hline & 3 & 7.53 & 8.78 & - & - & 8.78 & 614.85 \\
\hline \multirow{3}{*}{ SEP } & 1 & 7.55 & 9.00 & - & - & 9.00 & 614.22 \\
\hline & 2 & 7.69 & 8.71 & - & - & 8.71 & 613.78 \\
\hline & 3 & 7.42 & 8.98 & - & - & 8.98 & 613.11 \\
\hline \multirow{3}{*}{ OKT } & 1 & 7.98 & 8.50 & - & - & 8.50 & 612.88 \\
\hline & 2 & 8.26 & 9.09 & - & - & 9.09 & 612.53 \\
\hline & 3 & 8.33 & 9.55 & - & - & 9.55 & 611.93 \\
\hline \multirow{3}{*}{ NOP } & 1 & 9.29 & 12.35 & - & - & 12.35 & 610.16 \\
\hline & 2 & 10.62 & 14.25 & - & - & 14.25 & 608.10 \\
\hline & 3 & 11.73 & 14.25 & - & - & 14.25 & 606.00 \\
\hline
\end{tabular}


b. Realization of Selorejo Dam Operational Pattern

Table 5. Reservoir Operational Pattern

\begin{tabular}{|c|c|c|c|c|c|c|c|}
\hline \multirow{2}{*}{\multicolumn{2}{|c|}{$\begin{array}{l}\text { MONTH/ DAY } \\
\text { ELIN/UKK } \mathbf{m}^{3}\end{array}$}} & \multirow{3}{*}{ 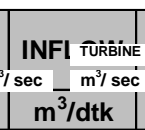 } & \multicolumn{4}{|c|}{ 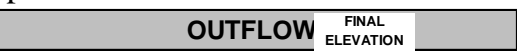 } & \multirow{3}{*}{$\begin{array}{c}\text { ELEVASI } \\
\text { AKHIR } \\
\mathbf{m}\end{array}$} \\
\hline & & & Tilingin & \multicolumn{2}{|c|}{ 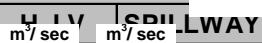 } & \multirow{2}{*}{$\begin{array}{l}\text { TOTAL } \\
\mathrm{m}^{3} / \mathrm{dtk}\end{array}$} & \\
\hline & & & $\mathrm{m}^{3} / \mathbf{d t k}$ & $\mathrm{m}^{3} / \mathrm{dtk}$ & $\mathrm{m}^{3 / \mathrm{dtk}}$ & & \\
\hline \multicolumn{2}{|c|}{ DEC } & & & & & & 612.00 \\
\hline \multirow{3}{*}{ DES } & 1 & 11.50 & 9.25 & - & - & 9.25 & 614.32 \\
\hline & 2 & \begin{tabular}{|l|}
10.17 \\
\end{tabular} & 9.25 & - & - & 9.25 & 614.73 \\
\hline & 3 & 11.70 & 9.25 & - & - & 9.25 & 615.98 \\
\hline \multirow{3}{*}{ JAN } & 1 & 14.44 & 9.25 & - & - & 9.25 & 617.91 \\
\hline & 2 & 23.79 & 12.96 & - & - & 12.96 & 621.37 \\
\hline & 3 & 21.64 & 14.00 & - & 9.25 & 23.25 & 621.04 \\
\hline \multirow{3}{*}{ FEB } & 1 & 16.25 & 14.00 & - & 3.25 & 17.25 & 620.69 \\
\hline & 2 & 17.93 & 14.00 & - & 1.04 & 15.04 & 621.50 \\
\hline & 3 & 26.46 & 14.00 & - & 15.38 & 29.38 & 620.89 \\
\hline \multirow{3}{*}{$\begin{array}{l}\text { MAR } \\
\text { MAY }\end{array}$} & 1 & \begin{tabular}{l|l}
17.35 \\
\end{tabular} & 14.00 & - & 3.15 & 17.15 & 620.97 \\
\hline & 2 & 16.89 & 14.00 & - & 1.88 & 15.88 & 621.19 \\
\hline & 3 & 15.45 & 14.00 & - & 0.45 & 14.45 & 621.47 \\
\hline \multirow{3}{*}{ APR } & 1 & 18.76 & 14.00 & - & 4.12 & 18.12 & 621.64 \\
\hline & 2 & 21.77 & 14.00 & - & 7.16 & 21.16 & 621.81 \\
\hline & 3 & 15.72 & 14.00 & - & 1.39 & 15.39 & 621.91 \\
\hline \multirow{3}{*}{ MEI } & 1 & 12.56 & 13.34 & - & - & 13.34 & 621.68 \\
\hline & 2 & 11.30 & 10.40 & - & - & 10.40 & 621.91 \\
\hline & 3 & \begin{tabular}{|l|}
13.85 \\
\end{tabular} & 13.60 & - & - & 13.60 & 622.00 \\
\hline \multirow{3}{*}{ JUN } & 1 & \begin{tabular}{|l|}
14.73 \\
\end{tabular} & 14.00 & - & 0.38 & 14.38 & 622.14 \\
\hline & 2 & \begin{tabular}{|l|}
13.89 \\
\end{tabular} & 14.00 & - & 0.31 & 14.31 & 621.92 \\
\hline & 3 & \begin{tabular}{|l|}
11.46 \\
\end{tabular} & 13.96 & - & - & 13.96 & 621.29 \\
\hline \multirow{3}{*}{ OCT } & 1 & 10.15 & 12.74 & - & - & 12.74 & 620.60 \\
\hline & 2 & 11.53 & 11.52 & - & - & 11.52 & 620.64 \\
\hline & 3 & 9.83 & 11.52 & - & - & 11.52 & 620.09 \\
\hline \multirow{3}{*}{$\begin{array}{l}\text { NOV } \\
\text { AGT }\end{array}$} & 1 & 8.74 & 11.52 & - & - & 11.52 & 619.18 \\
\hline & 2 & 8.42 & 11.09 & - & - & 11.09 & 618.28 \\
\hline & 3 & 8.19 & 10.45 & - & - & 10.45 & 617.21 \\
\hline \multirow{3}{*}{ SEP } & 1 & 7.40 & 9.53 & - & - & 9.53 & 616.42 \\
\hline & 2 & 7.42 & 9.37 & - & - & 9.37 & 615.66 \\
\hline & 3 & 7.47 & 9.25 & - & - & 9.25 & 614.90 \\
\hline \multirow{3}{*}{ OKT } & 1 & 7.72 & 9.25 & - & - & 9.25 & 614.14 \\
\hline & 2 & 7.81 & 9.25 & - & - & 9.25 & 613.41 \\
\hline & 3 & 9.38 & 9.25 & - & - & 9.25 & 613.53 \\
\hline \multirow{3}{*}{ NOP } & 1 & 9.47 & 10.31 & - & - & 10.31 & 613.09 \\
\hline & 2 & 11.66 & 10.87 & - & - & 10.87 & 613.62 \\
\hline & 3 & \begin{tabular}{|l|}
11.34 \\
\end{tabular} & 10.87 & - & - & 10.87 & 613.92 \\
\hline
\end{tabular}

\section{Conclusion:-}

Based on the result of debit model study with ARIMA model to determine reservoir operational pattern in Selorejo Dam, some conclusions are then obtained.

1. The best model in predicting Selorejo Dam debit inflow in period 2012/2013 is ARIMA Model $(1,1,1)(2,1,1)^{36}$, with the following equation:

$$
\begin{aligned}
& \mathrm{Z}_{\mathrm{t}}=2.36 \mathrm{Z}_{\mathrm{t}-1}-1.72 \mathrm{Z}_{\mathrm{t}-2}+0.36 \mathrm{Z}_{\mathrm{t}-3}-0.18 \mathrm{Z}_{\mathrm{t}-36}+0.42 \mathrm{Z}_{\mathrm{t}-37}-0.31 \mathrm{Z}_{\mathrm{t}-38}+0.06 \mathrm{Z}_{\mathrm{t}-39}-0.47 \mathrm{Z}_{\mathrm{t}-72}+1.11 \mathrm{Z}_{\mathrm{t}-73}- \\
& 0.81 \mathrm{Z}_{\mathrm{t}-74}+0.17 \mathrm{Z}_{\mathrm{t}-75}+0.66 \mathrm{a}_{\mathrm{t}-37}
\end{aligned}
$$

2. The criteria of goodness of ARIMA Model $(1,1,1)(2,1,1)^{36}$ is compared with the plan made by Perum Jasa Tirta I for Selorejo Dam debit inflow in period 2012/2013. It is shown in Table 6. 
Table 5:- Model's Criteria of Goodness.

\begin{tabular}{|c|c|c|}
\hline & ARIMA Model & \multirow{2}{*}{ PJT-I } \\
\hline MSE (Debit) & $(1,1,1)(2,1,1)$ & \\
\hline KAR (Debit) & 5.77 & 0.15 \\
\hline MAPE (Debit) & 0.15 & 6.53 \\
\hline MAD (Debit) & 9.67 & 2.46 \\
\hline MSD (Debit) & 2.02 & 13.49 \\
\hline T-test (Debit) & 8.08 & Not Meet Conditon \\
\hline T-test (Volume) & Meet Condition & Not Meet Conditon \\
\hline KR (Volume) & Meet Condition & 17.8 \\
\hline
\end{tabular}

3. The following is the comparison between the reservoir operational pattern in Selorejo Dam using debit inflow from ARIMA Prediction, the plan made by Perum Jasa Tirta (PJT) I and all realizations of both. The comparison is shown in Table 7.

Table 6:- The Comparison of Selorejo Dam Operational Pattern.

\begin{tabular}{|l|l|l|l|}
\hline \multirow{2}{*}{ Criteria } & Operational Pattern & Real \\
\cline { 2 - 4 } & ARIMA & 17.8 & - \\
\hline $\begin{array}{l}\text { KR } \\
\text { (Volume) }\end{array}$ & 5.50 & 339.31 & 412.78 \\
\hline $\begin{array}{l}\text { Volume } \\
\text { (million m3) }\end{array}$ & 390.08 & 30.04 & 35.03 \\
\hline $\begin{array}{l}\text { Electric Production } \\
\text { (Million MWh) }\end{array}$ & 33.53 & & \\
\hline
\end{tabular}

Table 7 indicates that reservoir operational pattern that is determined using debit inflow prediction from ARIMA model is closer to relization if understood from the difference in terms of volume and electric production.

\section{Suggestion:-}

1. In this study, Selorejo Dam debit inflow is determined using ARIMA in favor of short-term data prediction (1year), whereas for longer term prediction, ARFIMA is suggested.

2. The capacity of ARIMA should be compared with other method.

3. Result of debit prediction with ARIMA is also useful for other measurements, such as water allocation, planting pattern, water construction plan, and others.

\section{References:-}

1. Arsyad, L. (1994). Peramalan Bisnis. Yogyakarta: BPFE.

2. Box, G.E.P. and Jenkins, G.M. (1976). Time Series Analysis: Forecasting and Control. San Francisco: Holden Day.

3. Cryer, J.D. (1986). Time Series Analysis. Boston: PWS-KENT Publishing Company.

4. Hanke, J.E., Arthur G. Reitsch, and Dean W. Wichern. (2003). Peramalan Bisnis. Jakarta: PT. Prenhallindo.

5. Makridakis, S., S. C. Wheelwright dan V. E. McGee. (1988). Metode dan Aplikasi Peramalan. Jakarta: Erlangga.

6. Nigam, R., Sohail Bux, Sudhir Nigam, K.R. Pardasani, S.K. Mittal, Ruhi Haque. (2009). Time series modeling and forecast of river flow. Current World Environment Vol. 4(1), 79-87 (2009).

7. Republik Indonesia. (2010). Peraturan Pemerintah Republik Indonesia Nomor 37 Tahun 2010 Tentang Bendungan. Lembaran Negara Republik Indonesia Tahun 2010 Nomor 45. Jakarta: Sekretariat Negara.

8. Valipour, M., Mohammad Ebrahim Banihabib, Seyyed Mahmood Reza Behbahani. (2012). Parameters Estimate of Autoregressive Moving Average and Autoregressive Integrated Moving Average Models and Compare Their Ability for Inflow Forecasting. Journal of Mathematics and Statistics 8 (3): 330-338, 2012. 